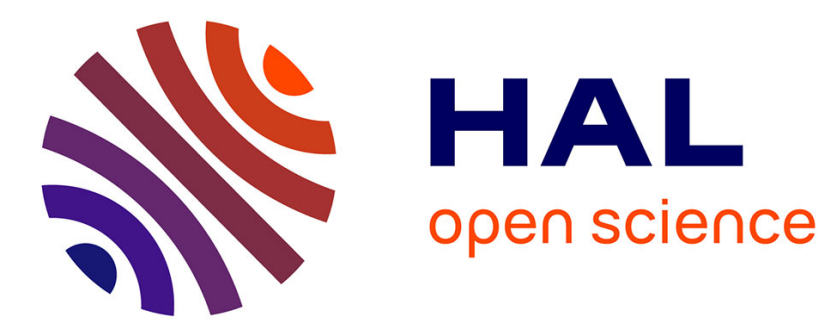

\title{
Structural Analysis of CoO-MgO System by XAFS
}

T. Yoshida, T. Tanaka, H. Yoshida, T. Funabiki, S. Yoshida, S. Hasegawa

\section{To cite this version:}

T. Yoshida, T. Tanaka, H. Yoshida, T. Funabiki, S. Yoshida, et al.. Structural Analysis of CoOMgO System by XAFS. Journal de Physique IV Proceedings, 1997, 7 (C2), pp.C2-1145-C2-1146. 10.1051/jp4:19972165 . jpa-00255229

\section{HAL Id: jpa-00255229 https://hal.science/jpa-00255229}

Submitted on 1 Jan 1997

HAL is a multi-disciplinary open access archive for the deposit and dissemination of scientific research documents, whether they are published or not. The documents may come from teaching and research institutions in France or abroad, or from public or private research centers.
L'archive ouverte pluridisciplinaire HAL, est destinée au dépôt et à la diffusion de documents scientifiques de niveau recherche, publiés ou non, émanant des établissements d'enseignement et de recherche français ou étrangers, des laboratoires publics ou privés. 


\title{
Structural Analysis of CoO-MgO System by XAFS
}

\author{
T. Yoshida, T. Tanaka, H. Yoshida, T. Funabiki, S. Yoshida and S. Hasegawa* \\ Department of Molecular Engineering, Kyoto University, Kyoto 606-01, Japan \\ * Department of Chemistry, Tokyo Gakugei University, Koganei, Tokyo 184, Japan
}

\begin{abstract}
CoO}-\mathrm{MgO}$ samples $\left(\mathrm{Co}_{\mathrm{x}} \mathrm{Mg}_{1-\mathrm{x}} \mathrm{O}: \mathrm{x}=\mathrm{mol} \mathrm{of} \mathrm{Co} /(\mathrm{mol}\right.$ of $\mathrm{Co}+\mathrm{mol}$ of $\mathrm{Mg})$ ) were prepared by impregnation of $\mathrm{MgO}$ powder with an aqueous solution of $\mathrm{CO}\left(\mathrm{NO}_{3}\right)_{2}$, followed by calcination at $773 \mathrm{~K}$. The atomic concentration range of Co for formation of a solid solution and the state of Co ions dissolving in the samples were investigated mainly by XAFS. XRD patterns showed that the dominant phase is $\mathrm{MgO}$ in the samples of $\mathrm{x}<0.3$ and the formation of small $\mathrm{Co}_{3} \mathrm{O}_{4}$ crystallite occurs in the samples of $x>0.3$. For the samples of $x>0.5$, the dominant phase was $\mathrm{Co}_{3} \mathrm{O}_{4}$ and the $\mathrm{MgO}$ phase was not detected by XRD. Co K-edge XANES spectra demonstrated that the octahedral symmetry around Co ions in the sample of $x=0.02$ is distorted in the samples of $x \geq 0.04$, indicating the change in the state of dissolved Co ions. Co Kedge EXAFS spectra revealed that $\mathrm{Co}$ ions dissolve into $\mathrm{MgO}$ matrix substitutionally in the samples of $\mathrm{x}<0.04$ while the phase separation due to the formation of the $\mathrm{Co}_{3} \mathrm{O}_{4}$ structure occurs in the samples of $\mathrm{x} \geq 0.04$.
\end{abstract}

\section{INTRODUCTION}

It is well known that $\mathrm{Ni}^{2+}, \mathrm{Co}^{2+}, \mathrm{Mo}^{2+}$ ions have a tendency to disperse into $\mathrm{MgO}$ lattice[1, 2]. Previously, we reported that $\mathrm{Ni}$ ions form a solid solution with $\mathrm{MgO}$ when the samples were prepared by impregnation of $\mathrm{MgO}$ powder with an aqueous solution of $\mathrm{Ni}\left(\mathrm{NO}_{3}\right)$, followed by calcination at $773 \mathrm{~K}[3]$. In the present work, we prepared CoO-MgO samples $\left(\mathrm{Co}_{\mathrm{x}} \mathrm{Mg}_{1-\mathrm{x}} \mathrm{O}: \mathrm{x}=\mathrm{mol}\right.$ of $\mathrm{Co} /(\mathrm{mol}$ of $\mathrm{Co}+\mathrm{mol}$ of $\mathrm{Mg})$ ) with the same method, and investigated the atomic concentration range of $\mathrm{Co}$ for formation of a solid solution and the state of Co ions dissolving in the samples mainly by XAFS.

\section{EXPERIMENTAL}

The measurement of Co K-edge X-ray absorption spectra was carried out on the beam line $6 \mathrm{~B}$ at Photon Factory in National Laboratory for High Energy Physics Tsukuba Japan with a ring energy $2.5 \mathrm{GeV}$ and stored current $200-350 \mathrm{~mA}$. (proposal No. 90144). X-ray absorption spectra were recorded in a transmission mode at room temperature with a $\mathrm{Si}(111)$ two-crystal monochromator. $\mathrm{Mg} \mathrm{K}$-edge X-ray absorption experiments were carried out on the beam line 7A at UVSOR, Institute for Molecular Science, Okazaki, Japan with a ring energy $750 \mathrm{MeV}$ and stored current 80-200 mA (proposal No. 4-C542). X-ray absorption spectra were reconded at room temperature in a total electron yield mode, using a two-crystal beryl monochromator. Normalization of X-ray absorption spectra and the extraction of their EXAFS oscillations were performed as described elsewhere[4, 5].

\section{RESULTS AND DISCUSSION}

\subsection{XRD}

XRD patterns showed that the dominant phase is $\mathrm{MgO}$ in the samples with $\mathrm{x}<0.3$ although the diffraction peaks attributed to $\mathrm{MgO}$ phase were slightly broader for the samples with $\mathrm{x}>0.15$. The formation of small $\mathrm{Co}_{3} \mathrm{O}_{4}$ crystalline was detected for the samples of $x \geq 0.3$ and the diffraction peaks due to $\mathrm{MgO}$ phase was not observed for the samples with $\mathrm{x}>0.5$.

\subsection{Co K-edge XAFS}

To clarify the change in the symmetry around a Co ion with the cobalt concentration $(x)$, Co K-edge XANES spectra of the samples were investigated. As for the sample with $x=0.02$, the pre-edge peak of XANES spectrum was as small as that of $\mathrm{CoO}$ reference sample with $\mathrm{CoO}_{6}$ octahedron. The pre-edge peak became more intense with an increase in $x$ and became almost the same size of that of $\mathrm{CO}_{3} \mathrm{O}_{4}$ in the range with $\mathrm{x} \geq 0.3$. As for the samples with $\mathrm{x} \geq 0.3$, the feature of $\mathrm{XANES}$ was also similar to that of $\mathrm{Co}_{3} \mathrm{O}_{4}$. These results indicate that the octahedral symmetry around a $\mathrm{Co}$ ion in the sample with $\mathrm{x}$ $=0.02$ is distorted in the sample with $x \geq 0.04$ and the spinel structure of $\mathrm{C}_{3} \mathrm{O}_{4}$ is formed at least in the samples with $x \geq$ 0.3 . 
Fig. 1 shows $\mathrm{k}$-weighted $\mathrm{Mg} \mathrm{K}$-edge EXAFS of $\mathrm{MgO}$ and $\mathrm{Co} \mathrm{K}$-edge EXAFS of the sample with $\mathrm{x}=0.02$. The pattems of these spectra are fundamentally the same, indicating that the surroundings around a Co ion in this sample is the same as that of the $\mathrm{Mg}$ ion. This result suggests that $\mathrm{Co}$ ions are substituted for $\mathrm{Mg}$ ions in $\mathrm{MgO}$. The small pre-edge peak in the XANES spectrum of this sample should imply that $\mathrm{Co}$ ions are octahedrally coordinated by oxygen due to the $\mathrm{Co}-\mathrm{Mg}$ substitution. In addition, the $\mathrm{k}^{3}$-weighted Co K-edge EXAFS of the sample of $x=0.02$ (Fig. 2a) was almost identical to the $\mathrm{k}^{3}$-weighted $\mathrm{Ni} \mathrm{K}$-edge EXAFS of $\mathrm{Ni}_{0.02} \mathrm{Mg} 0.98 \mathrm{O}$ solid solution,[3] supporting the formation of $\mathrm{Co}_{0.02} \mathrm{Mg} 0.98 \mathrm{O}$ solid solution. As shown in Fig. 2b, by increasing $x$ from 0.02 to 0.04 , the pattern of the $\mathrm{k}^{3}$-weighted EXAFS spectrum changes; especially the amplifude in the range of $k=3-7 \dot{A}^{-1}$ reduces remarkably. Taking into acconnt that the area of the pre-edge peak in XANES increases for the sample of $x=0.04$, the decrease in the amplitude of the spectrum would indicate the coexistence of the Co ions in different symmetries, that is the octahedral and a lower symmetry. The presence of Co ions in a lower symmetry may imply the formation of the distinct phase of cobalt oxide in the sample of $x=0.04$. The phase would be $\mathrm{Co}_{3} \mathrm{O}_{4}$ since the EXAFS pattern demonstrates that the dominant local structure around a $\mathrm{Co}$ ion is $\mathrm{Co}_{3} \mathrm{O}_{4}$ spinel structure even in the low cobalt concentration $x=0.11$ (Fig. 2c). On the basis of EXAFS patterns, it had been revealed that the local structure around a $\mathrm{Co}$ ion in the sample of $\mathrm{x} \geq 0.35$ is identical to the structure of $\mathrm{Co}_{3} \mathrm{O}_{4}$. Fig. $2 \mathrm{~d}$ shows the EXAFS spectrum of $x=0.35$ as an example. Since the EXAFS oscillation in the range of $k=12-15 \AA^{-1}$ is slightly weak compared to that of $\mathrm{Co}_{3} \mathrm{O}_{4}$ (Fig. 2e), it is expected that the particle size of the $\mathrm{CO}_{3} \mathrm{O}_{4}$ phase in the sample of $\mathrm{x}=0.35$ would be smaller than that of the $\mathrm{Co}_{3} \mathrm{O}_{4}$ reference sample. On the basis of the analyses of the Co K-edge XAFS mentioned above, we can conclude that the $\mathrm{Co}-\mathrm{MgO}$ solid solution is formed only in the range of $\mathrm{x}<0.04$. The phase separation resulting from the formation of $\mathrm{Co}_{3} \mathrm{O}_{4}$ structure probably occurs in the samples of $\mathrm{x} \geq 0.04$ in the short range order, although the phase separation can be detected only in the range of $0.3<\mathrm{x}<0.5$ by XRD.

We also investigated $\mathrm{Mg} \mathrm{K}$-edge XANES of the samples and found that the feature of $\mathrm{Mg} \mathrm{K}$-edge XANES of the samples of $\mathrm{x} \leq 0.8$ was almost the same as that of $\mathrm{MgO}$ regardless of the sample composition. This result supports that the separation of $\mathrm{MgO}$ phase from $\mathrm{Co}_{3} \mathrm{O}_{4}$ phase occurs in the wide range from $\mathrm{x}=0.04$ to at least $\mathrm{x}=0.8$.

As mentioned above, the tendency of a Co ion to dissolve into the $\mathrm{MgO}$ lattice is much different from that of a $\mathrm{Ni}$ ion. The formation of a Co-MgO solid solution by calcination at $773 \mathrm{~K}$ is difficult.

\section{References}

[1] A. P. Hagan, M. G. Lofthouse, F. S. Stone and M. A. Trevethan, Preparation of Catalysts II (Elsevier, Amsterdam, 1979) pp. 417438.

[2] G. C. Bond and S. P. Sarsam, Appl. Catal., 38 (1988) 365-377.

[3] T. Yoshida, T. Tanaka, H. Yoshida, T. Funabiki and S. Yoshida, J. Phys. Chem., 100 (1996) 2302.2309.

[4] T. Tanaka, H. Yamashita, R. Tsuchitani, T. Funabiki and S. Yoshida, J. Chem. Soc., Faraday Trans. 1, 84 (1988) $2987-2999$.

[5] J. Wong, F. W. Lytle, R. P. Messmer and D. H. Maylotte, Phys. Rev. B, 30 (1984) 5596-5610.

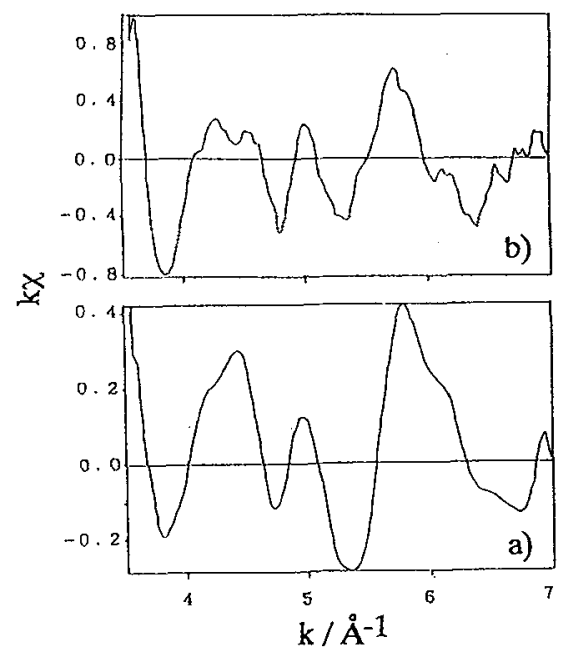

Figure 1: k-weighted $\mathrm{Mg} \mathrm{K}$-edge EXAFS of a) $\mathrm{MgO}$ and k-weighted Co K-edge EXAFS of b) $\mathrm{C}_{0} 0.02 \mathrm{Mg} 0.98 \mathrm{O}$.
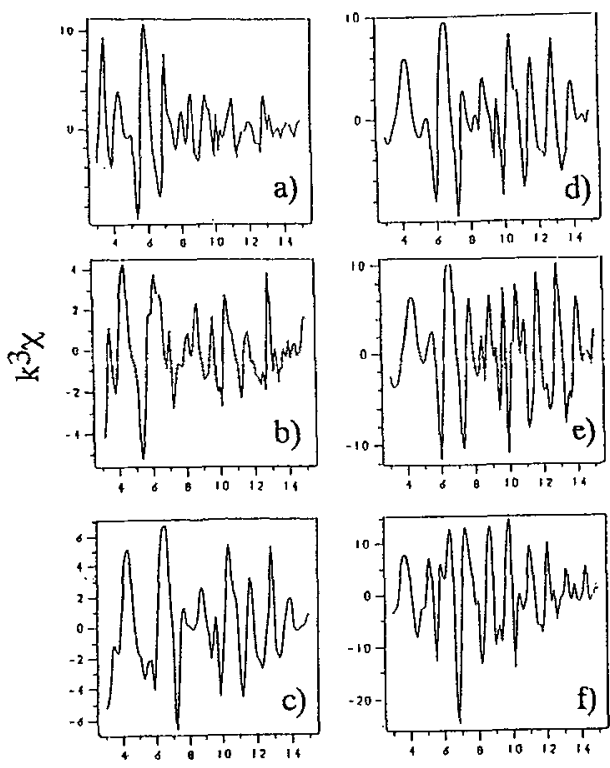

$\mathrm{k} / \AA^{-1}$

Figure 2: $\mathrm{k}^{3}$-weighted $\mathrm{Co} \mathrm{K}$-edge EXAFS of $\mathrm{Co}_{\mathrm{X}} \mathrm{Mg} 1-\mathrm{x}$ Ond $\mathrm{Co}_{3} \mathrm{O}_{4}$ and $\mathrm{CoO}$. a) $\left.\left.\mathrm{x}=0.02, \mathrm{~b}\right) \mathrm{x}=0.04, \mathrm{c}\right) \mathrm{x}=0.11 \mathrm{~d}$ ) $\mathrm{x}=0.35$, e) $\mathrm{Co}_{3} \mathrm{O}_{4}$ and $\left.\mathrm{f}\right) \mathrm{CoO}$. 